\title{
Early time course of the acute phase protein response in man
}

\author{
CM COLLEY, A FLECK, AW GOODE*, BR MULLER, MA MYERS
}

From the Department of Chemical Pathology, and ${ }^{*}$ Department of Surgery, Charing Cross Hospital Medical School, London W6 8RF

SUMMARY The rate at which the acute phase protein response occurred after both major and minor surgery was explored. Increases in the plasma concentration of C-reactive protein (CRP), alpha-1acid glycoprotein $\left(\alpha_{1} A G\right)$ and fibrinogen were not detected until $6-8 \mathrm{~h}$ after the initial incision. The peak concentration of CRP occurred at $48 \mathrm{~h}$ and that of fibrinogen at $96 \mathrm{~h} ; \alpha_{1} \mathrm{AG}$ concentrations rose rapidly until $48 \mathrm{~h}$ followed by little change until about $120 \mathrm{~h}$. Although there was widespread variation in the concentrations of individual proteins in patients, severity of injury did not seem to have a significant effect on the time course of the change. Plasma cortisol concentration and the total white blood cell count (WBC) reached their peaks before the acute phase proteins, cortisol at $6 \mathrm{~h}$ and $\mathrm{WBC}$ at $12 \mathrm{~h}$.

In recent years there has been considerable interest in the acute phase protein response to injury and the mediators involved in its control. ${ }^{1-3}$ The stimulus for the increase in concentration of these proteins in the blood appears to be non-specific, since the rises have been observed after many forms of tissue injury or bacterial infection. ${ }^{4}$ It has been suggested that measurement of these proteins, particularly C-reactive protein (CRP), can be used to confirm the presence of infection or disease. ${ }^{5}$ However, the measurements can be of little value until the temporal relations between the stimulus and the resulting changes in the plasma proteins have been defined.

A group of substances, collectively termed leucocyte endogenous mediator (LEM), synthesised by activated leucocytes, has been implicated in the initiation of the acute phase protein response. LEM stimulates hepatic RNA synthesis within a few hours in experimental animals ${ }^{6}$ and causes increased synthesis of acute phase proteins such as CRP, fibrinogen and haptoglobin, ${ }^{8}$ and caeruloplasmin. ${ }^{9}$ Corticosteroids have been shown to have a permissive effect in this process. ${ }^{10}$ Kushner and Feldman ${ }^{11}$ have shown that in rabbits there is a delay between the occurrence of trauma and hepatic synthesis of CRP as would be anticipated from the above hypothesis.

We have studied the early time course of the acute

${ }^{*}$ Present address: Surgical Unit, The London Hospital, London E1.

Accepted for publication 1 September 1982 phase protein response in humans. The relatively minor trauma of a surgical operation such as herniorrhaphy is a stimulus of suitably short duration. In addition neither blood nor intravenous fluids are usually administered during this operation and the interpretation of changes in plasma protein concentrations is therefore less complicated. The response in a small number of other operations was also studied for comparison.

\section{Material and methods}

Patients entering hospital for elective surgery were studied. There were 13 patients with unilateral hernias, three patients for cholecystectomy, four for varicose vein ligation and one case each of lymphnode biopsy, partial colectomy, total hip replacement and spinal fusion. No selection of patients was made within the groups. Samples of venous blood $(15 \mathrm{ml})$ were taken immediately prior to operation ( 0 time) and at various times after the initial skin incision. Samples were assayed for CRP, alpha-1-acid glycoprotein $\left(\alpha_{1} A G\right)$, fibrinogen, cortisol, albumin, haemoglobin, haematocrit and white blood cell count (WBC). In all cases protein concentrations were corrected by normalising the haematocrit to that before operation; where there is little blood loss during the operation this provides a method of correcting for any changes in fluid distribution between body compartments. 
The calculation used was $\mathrm{Pn}=\mathrm{Ps} \times \frac{\mathrm{Ho}}{\mathrm{Hs}}$

$\mathrm{Pn}=$ normalised protein concentration.

Ps = sample protein concentration.

Ho = haematocrit at time 0 .

Hs = haematocrit of the sample.

Clotted blood was collected for assay of the acute phase serum proteins and cortisol, and samples with EDTA as anticoagulant for fibrinogen, WBC and haematocrit. Serum was stored at $4^{\circ} \mathrm{C}$ until assayed, which was generally within seven days, and plasma was stored at $-20^{\circ} \mathrm{C}$ for up to two weeks, the proteins having been found to be stable under these conditions.

Antisera were purchased from Seward Laboratory, London, for CRP and fibrinogen, and from Dakoimmunoglobulins a/s, Denmark, for $\alpha_{1}$ AG. Standard human serum and plasma were obtained from Hoechst UK Ltd.

CRP, $\alpha_{1}$ AG and fibrinogen were assayed by an end-point immunonephelometric method using a Hyland Laser Nephelometer PDQ (Travenol Laboratories, Thetford, Norfolk, UK). Samples and standards were diluted into antiserum in the presence of polyethylene glycol, MW 4000 , at a concentration of $40 \mathrm{~g} / \mathrm{l}$, using an automatic diluter (Micromedic Systems, NY). Antiserum concentrations were chosen such that the highest expected results would fall well within the antibody excess portion of the calibration curve. All samples from one patient were generally assayed within the same batch and the intrabatch coefficients of variation for all assays were less than 5\%, except for CRP at concentrations below $10 \mathrm{mg} / \mathrm{l}$, where the $\mathrm{CV}$ was $11.5 \%$.

Albumin was assayed on a Technicon AutoAnalyzer using a bromocresol green method based on the procedure of Doumas $e t$ al $^{12}$ and using Bovine Albumin Standard Solution from Miles Laboratories Ltd (UK) as primary standard.

Plasma cortisol was determined by the fluorimetric procedure of Spencer-Peet et al. ${ }^{13} \mathrm{WBC}$ and haematocrit were measured on a Coulter Counter Model S.

The "normal" ranges for the acute phase proteins were:

CRP $<10 \mathrm{mg} / 1$

$\alpha_{1}$ AG $285-1000 \mathrm{mg} / \mathrm{l}$

Fibrinogen $1 \cdot 8-5 \cdot 0 \mathrm{~g} / \mathrm{l}$.

\section{Results}

The plasma concentrations of all the acute phase proteins studied were found to increase after herniorrhaphy. There was a delay of $6-8 \mathrm{~h}$ before increases in concentrations of any of the proteins were measurable. Thereafter the most rapid rise was shown by CRP which, as shown by others, ${ }^{14}$ reached a peak at about $48 \mathrm{~h}$ postoperation (Fig. 1). The peak concentration varied from $38 \mathrm{mg} / 1$ to $196 \mathrm{mg} / \mathrm{l}$ for seemingly equivalent hernia operations. There was no relation between peak concentration and age of the patient, or with postoperative progress. After the peak the concentration slowly fell and was still markedly raised at $144 \mathrm{~h}$. Similar results were obtained with other operations; cholecystectomy produced changes of comparable magnitude to herniorrhaphy, while Trendelenburg ligation of varicose veins produced a rise to only $36 \mathrm{mg} / \mathrm{l}$ and the concentration returned to normal by $144 \mathrm{~h}$ (Fig. 1). A single example of an inguinal lymph node biopsy produced a rise to $15 \mathrm{mg} / \mathrm{l}$.

After herniorrhaphy the delay mentioned above was followed by a rapid rise in $\alpha_{1} \mathrm{AG}$ concentration. This reached a plateau at about $48 \mathrm{~h}$ and remained raised until $120 \mathrm{~h}$, after which there was a decrease (Fig. 2). In the case of fibrinogen the lag period was again seen. The subsequent rise was much slower, reaching a peak at $96 \mathrm{~h}$ postoperation (Fig. 3). There was a decrease in fibrinogen and $\alpha_{1} \mathrm{AG}$ concentrations before the rise but this was not statistically significant.

A number of operations of greater severity than those described above were also studied including partial gastrectomy, partial colectomy, hip arthroplasty and spinal fusion. In many of these there was appreciable blood loss and transfusion and it is not possible to correct accurately for fiuid volume changes in the blood. However, essentially the same pattern of changes in CRP was seen and the

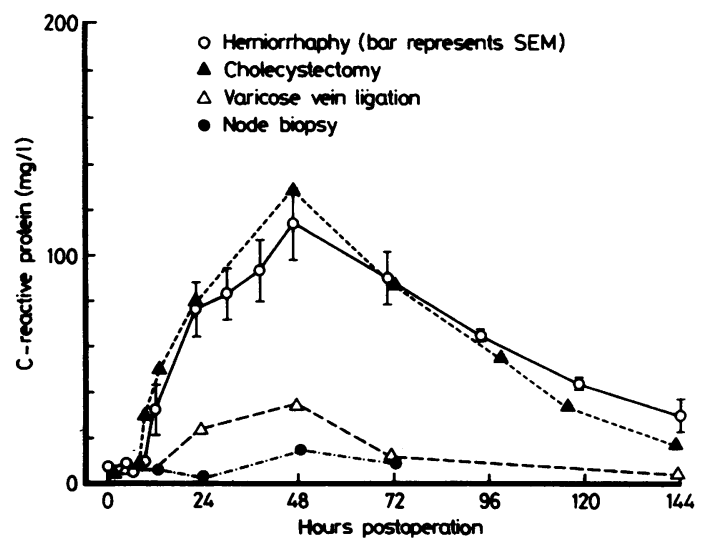

Fig. 1 Time course of serum $C$-reactive protein concentration changes after operation. 


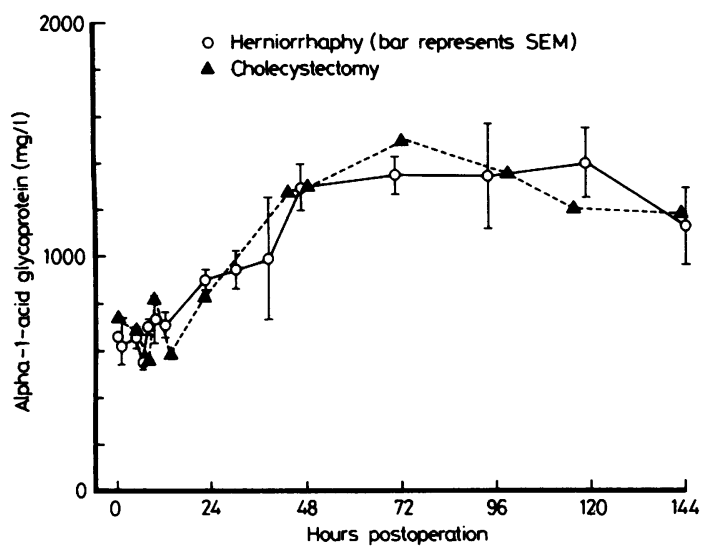

Fig. 2 Time course of serum alpha-1-acid glycoprotein concentration changes after operation.

maximum concentrations were no greater than those obtained after herniorrhaphy (Fig. 4). A similar pattern was observed even in cases where the concentrations of the acute phase proteins were raised prior to operation. For example, in a case of total hip replacement performed for an infected hip prosthesis the preoperative CRP concentration was $45 \mathrm{mg} / \mathrm{l}$. There was still a delay before any changes were seen in the concentrations of CRP, $\alpha_{1} A G$ and fibrinogen. The peak concentrations were again observed at similar times and the maximum concentrations were within the ranges obtained for herniorrhaphy. The same pattern was observed in a patient undergoing a partial colectomy for Crohn's disease where the preoperative CRP was $40 \mathrm{mg} / \mathrm{l}$ (Fig. 4).

The relations of changes in cortisol, WBC and

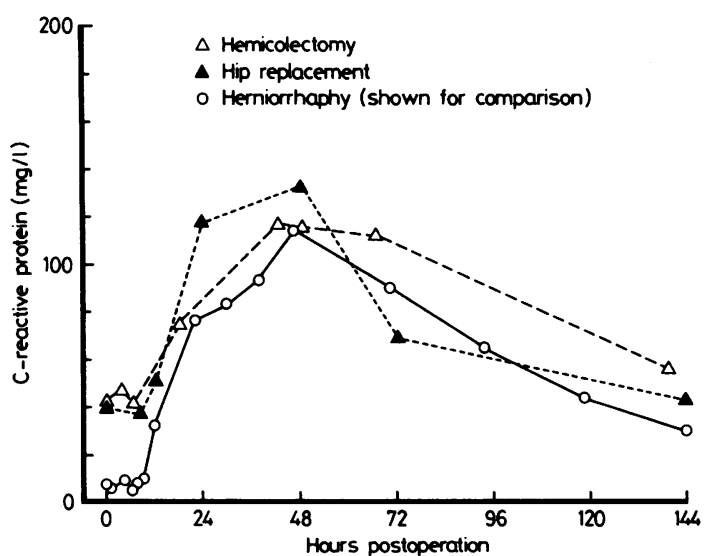

Fig. 4 Time course of serum $C$-reactive protein concentration changes after operations in which the preoperative CRP concentration had been raised.

acute phase proteins after herniorrhaphy are summarised in Fig. 5. The first change seen was an increase in cortisol, reaching a maximum at about $6 \mathrm{~h}$ postoperation. This was closely followed by an increase in the WBC, peaking at about $12 \mathrm{~h}$. No increases were seen in the concentrations of the acute phase proteins CRP, $\alpha_{1}$ AG and fibrinogen until 6$8 \mathrm{~h}$ after the beginning of the operation. C-reactive protein reached its maximum at approximately $48 \mathrm{~h}$ followed by $\alpha_{1} \mathrm{AG}$ and fibrinogen. There was no change in albumin concentration (after correction for haematocrit) in the herniorrhaphy patients, but there was a decrease in the cholecystectomy group, beginning during the operation and maximal at about $24 \mathrm{~h}$.

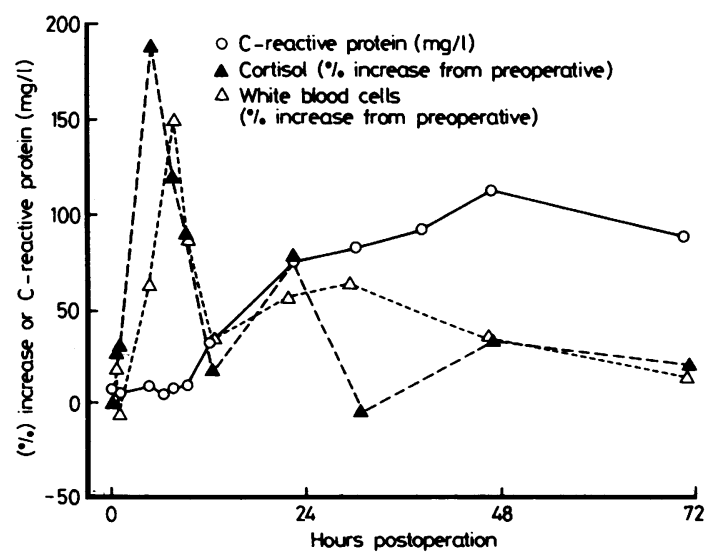

Fig. 5 Relation of changes in cortisol, white blood cells and CRP after herniorrhaphy.
Fig. 3 Time course of plasma fibrinogen concentration changes after operation. 


\section{Discussion}

An acute phase protein is a plasma protein the concentration of which increases in response to tissue damage. ${ }^{5}$ Previous studies of such changes have concentrated mainly on the effects after at least $24 \mathrm{~h}$, with little regard to the early period..$^{41417}$ Our studies show that there is a definite lag period between onset of trauma and the start of the increase in the concentrations of the acute phase proteins after surgery in man. In most cases it was not possible to exclude small changes in CRP concentration during the first $6-8 \mathrm{~h}$ postoperation since the measured values were at the lower limit of detection of our technique. However no changes were seen during this period in the three patients studied in whom the concentrations were raised prior to surgery. The sensitivities of the methods used for fibrinogen and $\alpha_{1} A G$ were, however, adequate to detect small deviations from the basal concentrations and neither of these proteins showed any increase from preoperative concentrations until $6-8 \mathrm{~h}$ after the initial skin incision.

The increases in the concentrations of the proteins are unlikely to be due to fluid shifts. There was little blood loss during herniorrhaphy (less than $50 \mathrm{ml}$ ) and any loss should lead to a fall in plasma protein concentration. ${ }^{18}$ Changes due to posture can be eliminated because patients were lying in bed for several hours both before and after operation. The effects of early mobilisation can also be ruled out because moderate exercise increases plasma protein concentration by not more than $15 \%$ and the concentration returns to the previous value after 25 minutes of rest. ${ }^{19}$

The magnitude of the response appeared to be proportional to the degree of trauma only for small injuries such as node biopsy and varicose vein ligation (Fig. 2). A maximal response was obtained with herniorrhaphy, which we had originally assumed would represent minimal trauma; the concentrations reached with partial gastrectomy, orthopaedic operations or cholecystectomy were of the same order as those seen after herniorrhaphy (Fig. 5). Even where the CRP concentration was raised before operation there was no additional increase in magnitude of response; in fact the increase was considerably less than in those patients with low initial concentrations. It is tempting to suggest that after surgery there is a maximal capacity for production of the acute phase proteins, and that this capacity is reached with only a limited degree of trauma. Our conclusions in this study vary from those of Dominioni et al who suggested that there was a close correlation between increases in CRP concentration and the magnitude of operation. ${ }^{20}$

Since the acute phase proteins in this study are synthesised in the liver it is necessary to postulate a mechanism for transmitting a signal from the site of injury. The temporal relation of peak values of cortisol, WBC and acute phase proteins demonstrated here are consistent with the current concept that infection and, we suggest, trauma, lead to the release of substances from damaged cells which stimulate leucocytes to produce a series of polypeptides including leucocyte endogenous mediator (LEM) and endogenous pyrogen (EP), which in turn have a variety of effects on different tissues and organs. An important effect on the liver is to promote increased synthesis of the acute phase proteins. ${ }^{6}$

Changes seen in the concentration of these proteins must be assessed in the light of the length of time since the injury. Because of the lag period the acute phase proteins are not good indicators of the current state of the patient; they could not be used to assess hour to hour progress of inflammation or infection because increases in the concentration of acute phase proteins in plasma relate to an event of at least $6-8 \mathrm{~h}$ previously.

Using a radioimmunoassay method for CRP, which is of greater sensitivity than the nephelometric method, we have confirmed the existence of a lagphase before increase in serum CRP concentration after operation.

We should like to thank the Department of Haematology, Charing Cross Hospital for the WBC and haematocrit results.

\section{References}

Koj A. Acute-phase reactants. In: Allison AC, ed. Structure and function of plasma proteins. London and New York: Plenum Press, 1974:73-125.

' Gordon $\mathrm{AH}$, The acute-phase plasma proteins. In: Bianchi R, Mariani G, McFarlane AS, eds. Plasma protein turnover. London: MacMillan Press Ltd, 1976:381-94.

${ }^{3}$ Kampschmidt RF. Leukocytic endogenous mediator. J Reticuloendothel Soc 1978;234:287-97.

+ Belfrage S. Plasma protein pattern in the course of acute infectious disease. Acta Med Scand 1963;suppl 395.

' Pepys MB. C-reactive protein, serum amyloid-P-component and serum amyloid A protein in autoimmune disease. In: Holbrow $\mathrm{EJ}$, ed. Clinics in immunology and allergy. London, Philadelphia, New York: WB Saunders, 1981:1:77-101.

- Wannemacher RW Jr, Pekarek RS, Thompson WL et al. A protein from polymorphonuclear leucocytes (LEM) which affects the rate of hepatic amino acid transport and synthesis of acute phase globulins. Endocrinology 1975;96:651-61.

'Merriman CR, Pulliam LA, Kampschmidt RF. Effect of Leucocytic endogenous mediator on $\mathrm{C}$-reactive protein in rabbits. Proc Soc Exp Biol Med 1975;149:782-4.

${ }^{8}$ Kampschmidt RF, Upchurch HF. Effect of leukocyte endogenous mediator on plasma fibrinogen and haptoglobin. Proc Soc Exp Biol Med 1974;146:904-7.

- Pekarek RS, Powanda MC, Wannemacher RW Jr. The effect of leukocyte endogenous mediator (LEM) on serum copper and ceruloplasmin concentrations in the rat. Proc Soc Exp Biol Med 1972;141:1029-31. 
"Thompson WL, Abeles FB, Beall FA, Dinterman RE, Wannemacher RW Jr. Influence of the adrenal glucocorticoids on the stimulation of synthesis of hepatic ribonucleic acid and plasma acute-phase globulins by leukocytic endogenous mediator. Biochem J 1976;156:25-32.

"Kushner I, Feldman G. Control of the acute phase response: demonstration of $\mathrm{C}$-reactive protein synthesis and secretion by hepatocytes during acute inflammation in the rabbit. $J$ Exp Med 1978;148:466-77.

12 Doumas BT, Watson WD, Briggs HG. Albumin standards and the measurement of serum albumin with bromocresol green. Clin Chim Acta 1971;31:87-96.

13 Spencer-Peet J, Daly JR, Smith V. A simple method for improving the specificity of the fluorimetric determination of adrenal corticosteroids in human plasma. $J$ Endocrinol 1965;31:235-44.

${ }^{14}$ Fischer GL, Gill C, Forrester MG, Nakamura R. Quantitation of "acute phase proteins" postoperatively. Am J Clin Pathol 1976;66:840-6.

is Crockson RA, Payne CJ, Ratcliffe AP, Soothill JF. Time sequence of acute phase reactive proteins following surgical trauma. Clin Chim Acta 1966;14:139-46. in Ballantyne FC. Fleck A. The effect of environmental temperature $\left(20^{\circ}\right.$ and $\left.30^{\circ}\right)$ after injury on the catabolism of albumin in man. Clin Chim Acta 1973;46:139-46.

${ }^{17}$ Fleck $A$. The influence of the nature, severity and environmental temperature on the response to injury. In: Wilkinson AW, Cuthbertson D, eds. Metabolism and the response to injury. London: Pitman Medical, 1976:44-8.

1* Skillman JJ, Awwad HK, Moore FD. Plasma protein kinetics of the early transcapillary refill after haemorrhage in man. Surg Gynecol Obstet 1967;125:983-96.

${ }^{14}$ Kaltreider NL, Meneely GR. The effect of exercise on the volume of the blood. J Clin Invest 1940;19:627-34.

20 Dominioni L, Dionigi R, Cividini F. Determination of C-reactive protein and alpha-1-antitrypsin for quantitative assessment of surgical trauma. Eur J Surg Res 1980;suppl, 1:133.

Requests for reprints to: Dr CM Colley, Department of Chemical Pathology, Charing Cross Hospital Medical School, London W6 8RF, England. 